\title{
Openness and the Exchange Rate Exposure of National Stock Markets - a Note *
}

\author{
Richard Friberg \\ Stockholm School of Economics, P.O. Box 6501, \\ S-11383 Stockholm, Sweden,nerf@hhs.se \\ Stefan Nydahl, \\ Uppsala University, P.O. Box 513 \\ S-751 20,Uppsala, Sweden,Stefan.Nydahl@nek.uu.se
Working Paper Series in Economics and Finance No. 195
September 1997

\begin{abstract}
This paper examines the relationship between the valuation of the stock market and an effective exchange rate. We use monthly data on 10 industrialized countries for the period 1973-1996. We find that the more open the economy, the stronger is the (positive) relationship between return on the stock market and the exchange rate. The pattern that we find is consistent with the well documented findings of less than full pass-through of exchange rates into import prices.
\end{abstract}

Keywords: Exchange rate pass-through; exchange rate exposure

JEL: F30; G10

\footnotetext{
* The authors would like to thank Anders Vredin and seminar participants at the Stockholm School of Economics and Sveriges Riksbank for valuable comments. Financial support from Bankforskningsinstitutet is gratefully acknowledged.
} 
Is the relationship between stock market value and the exchange rate (exchange rate exposure) stronger in a more open economy than in a more closed economy? Our interest in this issue was spurred by the very limited evidence of a statistically significant relationship between exchange rates and market valuation of firms (see e.g. Jorion, 1990, Bodnar and Gentry, 1993, Bartov and Bodnar, 1994). Many observers have found this lack of significance surprising ${ }^{1}$. However, most of the empirical work cited above uses data from a relatively closed economy, the United States. Potentially this could account for the limited stock price responses to exchange rate surprises. In their study on the exchange rate exposure of a sample of British firms, Donnelly and Sheehy (1996, p. 163) point out that "Our analysis has found a contemporaneous relationship between the exchange rate and a portfolio of export-intensive companies. We attribute the difference between our findings and those of U.S. research to the fact that the U.K. is a far more open economy than that of the U.S. and that our sample firms are more export intensive than those used in prior U.S. based research."

Conventional wisdom says that (the firms in) a more open economy should be affected stronger by changes in the exchange rate than that of a more closed economy as long as money is not neutral. In a more open country a larger share of the average firm's transactions should be related to exchange rate changes, through exports, imports or competition from foreign firms. One possible research strategy for studying this issue is to study the dispersion of exchange rate exposure between the same industries based in different countries. The task that we set for ourselves in this paper is more humble in the sense that we examine the exchange rate exposure of national stock markets. The advantage of our strategy is that we are able to expand the number of markets studied at a low cost. By studying the stock market index we also implicitly study how importing and import-competing firms are affected by exchange rate

\footnotetext{
${ }^{1}$ Chow, Lee and Solt (1997, p. 105) for instance state that "More puzzling is that analyses thus far have failed to substantiate a statistically significant relationship [between firm value and exchange rates]"
} 
surprises - this is in contrast to the literature on exchange rate exposure that has focused on exporting firms.

The relationship between the valuation of the stock market and an effective exchange rate for 10 industrialized countries is examined. Monthly data for the period 1973-1996 are used. We establish a significant positive relationship between exchange rate exposure on the stock market and openness.

In section I we discuss related literature. Section II presents our empirical analysis and section III contains a discussion of our findings. We claim that if firms tend to keep prices stable in the importer's currency (less than full exchange rate pass-through) this should lead to the kind of pattern that we observe. Section IV concludes and makes suggestions for further research.

\section{Exchange rate exposure}

In the literature on exchange rate exposure it is common practice to divide exposure into economic and accounting exposure. Accounting exposure is concerned with the effect of exchange rate surprises on the accounting value of assets and liabilities. Economic exposure for a firm measures the extent to which a firm's value, defined as the expected value of future cash flows, changes with the exchange rate. This is a much more general and relevant measure of exchange rate exposure than accounting measures, but also more complex. It is hard to identify all, or even a small part of, the individual components of economic exposure ${ }^{2}$. A simple approach has however been suggested by Adler and Dumas (1984). They show that the economic exposure for a firm is equal to the slope coefficient(s) from a regression of the change in the firm's value as the dependent variable and changes in exchange rates as the

\footnotetext{
${ }^{2}$ Theoretical work exploring the link between exchange rate exposure and industrial organization issues is extremely scarce. Marston (1996) and Friberg (1997) are two exceptions.
} 
regressor(s). This approach has been used in several empirical studies (e.g. Jorion, 1990 and Bartov and Bodnar, 1994).

It is quite plausible that firms' exchange rate exposure differs between countries. Companies in more open countries might on average be more sensitive to international conditions than companies in a large, less open economy. Therefore the lack of studies presenting and comparing results for different countries is somewhat surprising. One step in this direction is made by Bodnar and Gentry (1993). They study industries in Canada, Japan and the United States and find (weak) support for the hypothesis that the value of industries in more open economies (Canada, Japan) are more influenced by exchange rate changes than in a more closed economy (the US).

Of course exchange rate exposure can not be interpreted as the effect of purely exogenous movements in the exchange rate on the value of a firm. The estimate of exchange rate exposure may reflect that exchange rates and stock prices are driven by the same shocks. This is all the more relevant if one studies the exchange rate exposure of an entire stock market as opposed to studying the exposure of an individual firm. Ibrahimi, Oxelheim and Wihlborg (1995) study how stock market returns are affected by macroeconomic shocks in Japan, U.S. and Sweden for the period 1970-1987. When they regress real stock market return on anticipated and unanticipated changes in monetary variables (exchange rate, money supply, short-term interest rates), the coefficient on the exchange rate turns out insignificant. They take this to signify that exchange rates are not an independent source of risk or that exchange rate risk is diversified in national stock markets. One may also recognize that developments in the stock market may influence monetary policy and interest rates. This would perhaps lead one to prefer a VAR analysis, to see how e.g. interest rates, equity returns and inflation respond to money supply shocks. Lastrapes (1996) is an example of that methodology.

We choose in this paper to stay close to the tradition in the exchange rate exposure literature, that of including the exchange rate as the only independent variable in our main analysis. This 
makes comparison easy with the findings from the exchange rate exposure literature. As a robustness check we also run regressions that include interest rates and return on a world market portfolio as explanatory variables, as well as regress real stock market return on real exchange rates.

\section{II . The exchange rate exposure of national stock indexes}

To measure national stock market's exposure to exchange rate fluctuations we follow Adler and Dumas (1984) and estimate the following equations,

$$
R_{i, t}=\beta_{0, i}+\beta_{1, i} \Delta S_{i, t}+\varepsilon_{i, t}, \quad \mathrm{i}=1, \ldots \ldots \ldots \mathrm{N} . \quad \mathrm{t}=1, \ldots \ldots . \mathrm{T} .
$$

For market $i$ at time $t R_{i, t}$ is the return on the national stock market (percentage change in the stock index), $\Delta S_{i, t}$ is the percentage change in a country specific, trade weighted, exchange rate index and $\varepsilon_{i, t}$ is an error term. The return on the respective national stock market is based on stock market data from Morgan-Stanley that are comparable across countries. The data that we use are described in appendix 1. The trade weighted exchange rate index is calculated for each country using IMF's Multilateral Exchange Rate Model (MERM) weights ${ }^{3}$. A positive change in the index indicates a depreciation, so for a country with a heavily export-oriented industry one would expect a positive sign of $\beta_{1, i}$. Equation (1) was estimated for 10 industrialized countries with Ordinary Least Squares (OLS) regression. Monthly data for the period 1973:1-1996:08 were used. Results are presented in the first column of table 1.

table 1 about here

\footnotetext{
${ }^{3}$ The 1977-based weights that we use are reported in International Monetary Fund (IMF), (1985).
} 
It seems like exchange rate movements indeed have an effect on stock markets. The sign of the estimated slope coefficients are positive for most countries indicating that the stock market goes up when the exchange rate is depreciating. For instance, over the period a percentage depreciation of the Danish krona has on average been associated with a 0.66 percent increase of the Danish stock market value. Looking at the individual estimates, the impact of exchange rate movements on the stock market is highly significant for some countries, but for others it seems close to zero. These results are quite similar to earlier findings for individual firms and industries. Jorion (1990) found significant exposure for less than 10 percent of his sample of US firms. Bodnar and Gentry (1993) found significant exposure coefficients for 28 percent of the US industries, for 21 percent of the Canadian and for 35 percent of the Japanese industries included in their study. The explanatory value of regressions is low and are not reported here in order to save space. The adjusted $\mathrm{R}^{2}$ ranges from close to 0 to 0.10 for equation (1). The low explanatory value is also in line with earlier findings for individual firms and industries.

Specifications (2) -(3) show that the point estimates of exchange rate exposure are not very sensitive to the inclusion of a world market portfolio (2) or interest rates $^{4}$ (3) as explanatory variables. Inclusion of the world market portfolio lowers the standard deviation on the estimated exchange rate exposures. It also results in much higher explanatory values of regressions, adjusted $\mathrm{R}^{2}$ for specification (2) are generally much higher than for (1) and range from 0.07 to 0.78 . Return on a world market portfolio is thus an important determinant of return on these national stock markets. Inclusion of interest rates as explanatory variable (3) tends to decrease the significance of the coefficient on the exchange rate. The probable reason for this is that both the exchange rate and the interest rate are partly affected by the same domestic shocks which implies multicollinearity. In equation (4) we use the "local" stock market index (e.g. Nikkei, S\&P 500) as dependent variable, we then have a sample of 13 countries.

\footnotetext{
${ }^{4}$ Bond yield on long-term bonds, (heading 61 in IFS, 5-10 years). This was the interest rate that was most consistently available over the period and the countries studied.
} 
We have experimented with different sample periods (also extending the sample period back to $1957)$ as well as with another measure of the effective exchange rate ${ }^{5}$ The general pattern that we find (positive or zero exposure) seems to be quite robust for this sample of countries.

The estimated exposure coefficient can be interpreted as the average exposure of the firms in the stock market to changes in the exchange rate. We now proceed by relating the estimated exposure for a country to the degree of openness for that country. Figure 1 below plots the estimated exchange rate exposure coefficients from table 1 (specification (1)) against a measure of the openness of the respective economy.

figure 1 about here

A more open economy seems to show a stronger relationship between return on the stock market and exchange rate changes. To formally test this hypothesis we state that the exposure can be written as a linear function of the degree of openness,

$$
\beta_{1, \mathrm{i}}=\alpha_{0}+\alpha_{1} \text { Openness }_{\mathrm{i}}+u_{\mathrm{i}} \quad \mathrm{i}=1, \ldots \ldots ., \mathrm{N}
$$

where $\beta_{1, \mathrm{i}}$ is the estimated exposure for country $i$ from equation (1), Openness is defined as the average (import+export)/GDP ratio over the study period and $u_{\mathrm{i}}$ is an error term. The coefficients $\alpha_{0}$ and $\alpha_{1}$ in equation (5) can be estimated using a two step approach where in the first step the exposure coefficients are estimated from equation (1) and in the second step we use these coefficients as dependent variables in an Ordinary Least Squares regression to estimate equation (5). An alternative specification would be to substitute $\beta_{1, i}$ by $\alpha_{0}+\alpha_{1}$ Openness $_{\mathrm{i}}$ into equation (1) and estimate $\alpha_{0}$ and $\alpha_{1}$ directly by Generalized Least Squares (GLS),

\footnotetext{
${ }^{5}$ The effective nominal exchange rates in the International Monetary Funds IFS data base (TCW).
} 


$$
R_{i, t}=\beta_{0, i}+\left(\alpha_{0}+\alpha_{1} \text { Openness }_{i}\right) \Delta S_{i, t}+\mu_{i, t} \quad i=1, \ldots \ldots . \mathrm{N} \quad t=1, \ldots \ldots \mathrm{T}
$$

The OLS and GLS estimates of the coefficient of openness, $\alpha_{1}$, are both significant at the $1 \%$ level and indicate a positive relation between the magnitude of exposure and the degree of openness. The point estimate of $\alpha_{1}$ using OLS is 0.77 and 0.56 using GLS ${ }^{6}$.

\section{Discussion}

One should be careful not to exaggerate our result that stock markets in more open countries are more exposed to exchange rate changes than stock markets in more closed countries. The number of countries in our sample is low. Nevertheless, a discussion of the result is in place. The more open a country, the more is the business of the typical firm related to foreign trade and thus potentially exposed to exchange rates. Our finding that more openness implies a stronger positive relationship between stock market valuation and the exchange rate does not follow immediately from this however. One would expect that some activities should be affected positively (primarily exports) and some negatively (importing or import-competing). These effects on the stock market index could very well cancel.

One explanation for the pattern that we find is related to recent findings of how prices of traded goods respond to exchange rate changes ${ }^{7}$. A stylized fact is that import prices, for a wide range of goods, respond less than proportionately to exchange rate changes. Menon (1995) and Goldberg and Knetter (1996) summarize the literature. For instance 40 out of the

\footnotetext{
${ }^{6}$ The point estimate of $\alpha_{1}$ using GLS and specificication (2), (3) and (4) are 0.61, 0.60 and 0.33 respectively, all significant at the $5 \%$ level.

${ }^{7}$ Dumas (1994) and Friberg (1997) are two, of but a few papers, that make the connection between exchange rate pass-through and exchange rate exposure.
} 
46 studies surveyed by Menon find less than complete exchange rate pass-through - a less than proportionate response of import prices to exchange rate changes.

Limited price responses (in the importer's currency) imply limited quantity responses relative to what would be the case if import prices were allowed to be affected more by exchange rate changes. A low exchange rate pass-through should imply that the value of importing and import-competing firms should tend to be affected little by exchange rate surprises. If the input prices of an importing firm change little when the exchange rate changes, there should be little direct effect on the value of that firm from exchange rate fluctuations. Similar reasoning applies to an import-competing firm.

Exporting firms will be affected positively by a depreciation even in the case of no exchange rate pass-through (if they are not fully hedged). If prices are kept stable in the importer's currency demand will be affected little by exchange rate changes. This stabilizes total revenues in foreign currency. The value of an exporter will then be affected positively by a depreciation since foreign revenue is being translated into the home currency at a more favorable exchange rate. Limited exchange rate pass-through thus implies that we should expect a positive influence from an exchange rate depreciation on the valuation of the stock market. Exporting firms will tend to be affected positively by a depreciation and effects will tend to be stronger for exporting than for importing or import-competing firms. The more open the economy the larger is the share of internationally trading companies on a national stock market. Limited exchange rate pass-through should thus lead us to predict a pattern of openness and exchange rate exposure of national stock indexes as that we observed in section II.

Given the low variability of consumer price indexes in relation to exchange rates and equity prices we expect the pattern of openness and exposure that we have found earlier to hold also if we regress real stock market returns on real exchange rates. The first column in table 2 below presents point estimates from such regressions. The GLS point estimate of the openness coefficient is 0.35 , which is significant at the $5 \%$ level. 
table 2 about here

Another potentially interesting question is how exposed a national stock market is to different regions and currencies. The second column in table 2 reports exchange rate exposure coefficients against the US dollar and column three reports exposure against an "small EMU effective exchange rate"(Austria, Belgium, Germany, France, Netherlands; calculations are described in appendix 2). The estimated exposure coefficients against the dollar are remarkably similar to the ones for the small EMU (but generally lower than the exposure to the MERM exchange rate which we reported in table 1). One explanation for the similarity of coefficients is that the correlation between a country's effective exchange rates against various regions is high, domestic shocks and news will generally affect a country's exchange rates against various regions similarly. We have also experimented with regressions where we separated the total exchange rate exposure into different regions. Appendix 2 reports the results from some regressions of that kind. Point estimates are generally insignificant (likely due to multicollinearity) and were also quite sensitive to the time period chosen.

\section{Concluding remarks}

This paper has established a positive relationship between stock market exposure to exchange rates and the openness of a country for 10 (13) industrialized countries in the post BrettonWoods period. Could the effect of openness on the correlation between stock market valuation and exchange rate changes, that we have documented above, be spurious? The best way to study these issues would be to empirically test a fully worked out model that incorporates financial issues with issues of monetary non-neutrality and international Industrial Organization (limited pass-through, segmented goods markets). That is indeed a formidable task. A perhaps more promising direction for research is to study the exchange rate exposure of similar 
industries in many countries. One would be interested in export intensive industries as well as in importing and import-competing industries.

In this paper we have only studied the contemporaneous relationship between stock market valuation and the exchange rate. As explored by Bartov and Bodnar (1994) and Chow, Lee and Stolt (1997) adjustment may be a more drawn out process which would lead to inclusions of lagged explanatory variables in regressions. We leave these questions for future research.

There is clearly a need for more formal theoretical analysis in the studies of exchange rate exposure. Our present work points to that it should be fruitful to further integrate issues of exchange rate pass-through and exchange rate exposure. 


\section{References}

Adler, M. and B. Dumas (1984) Exposure to currency risk: definition and measurement, Financial Management, 41-50.

Bartov, E. and G.M. Bodnar (1994) Firm valuation, earnings expectations, and the exchangerate exposure effect, The Journal of Finance 44, 1755-1785.

Bodnar, G.M. and W.M. Gentry (1993) Exchange rate exposure and industry characteristics: evidence from Canada, Japan and the USA, Journal of International Money and Finance 12, $29-45$.

Chow, E.H., Lee, W.Y. And M.E. Stolt (1997) The exchange-rate risk exposure of asset returns, Journal of Business 70, 105-123.

Donnelly, R. and E. Sheehy (1996) The share price reaction of U.K. exporters to exchange rate movements: an empirical study, Journal of International Business Studies, 157-165.

Dumas, B. (1994) Short- and long-term hedging for the corporation, CEPR Discussion Paper no. 1083 .

Friberg, R.C. (1997) Prices, profits and exchange rate uncertainty: the case of Bertrand competition in differentiated goods, manuscript, Stockholm School of Economics. 
Goldberg, P.K. and M.M. Knetter (1996) Goods prices and exchange rates: what have we learned? NBER Working Paper no. 5862.

Ibrahimi, F., Oxelheim, L. and C. Wihlborg (1995) International stock markets and fluctuations in exchange rates and other macroeconomic variables. In Global Portfolio Diversification: Risk Management, Market Microstructure and Implementation Issues, eds. R. Aggarwal and D. Schirm, Academic Press, Boston.

International Monetary Fund (1985) Supplement on exchange rates, International Financial Statistics, Supplement Series, No. 9.

Jorion, P. (1990) The Exchange Rate Exposure of U.S. Multinationals, Journal of Business 63, 331-345.

Lastrapes, W.D. (1996) International evidence on equity prices, interest rates and money, manuscript, University of Georgia.

Marston, R.C. (1996) The effects of industry structure on economic exposure, NBER Working Paper no. 5518.

Menon, J. (1995) Exchange rate pass-through, Journal of Economic Surveys 9, 197-231. 
Appendix 1 - Data description

The Morgan-Stanley stock market indexes and world market index are from Morgan-Stanley. For all countries they are adjusted for dividends.

Data on national Consumer Price Indexes, nominal exchange rates and "local" stock market data were collected from the Ecowin database. The stock market index used for different countries are presented below.

Country Stock Market Index

$\begin{array}{ll}\text { Austria } & \text { ATX } \\ \text { Belgium } & \text { BEL20 } \\ \text { Switzerland } & \text { BK IND. } \\ \text { Germany } & \text { DAX } \\ \text { Denmark } & \text { COPENHAGEN SE } \\ \text { Finland } & \text { HEX } \\ \text { France } & \text { CAC 40 } \\ \text { Italy } & \text { MIB } \\ \text { Japan } & \text { NIKKEI } \\ \text { Netherlands } & \text { CBS } \\ \text { Norway } & \text { All stocks } \\ \text { Sweden } & \text { AFGX } \\ \text { USA } & \text { S\&P 500 }\end{array}$

Interest rates, yield on long-term government bonds, were collected from the International Monetary Funds IFS data base, (heading 61). The term length is for 5-10 years depending on the country.

The IFS data base was also the source for the data used when calculating Openness; Gross Domestic Product (heading 99b), total value of exports (heading 90c) and total value of imports (heading 98c). 
Appendix 2 - Exchange rate exposure; different areas

We run two sets of regressions,

$$
\begin{aligned}
& R_{i, t}=\theta_{a, 0, i}+\theta_{S E M U, i} \Delta S_{S E M U, i, t}+\theta_{a, U S A, i} \Delta S_{U S A, i, t}+\theta_{R O W 1, i} \Delta S_{R O W 1, i, t}+\varsigma_{a, i, t} \\
& R_{i, t}=\theta_{b, 0, i}+\theta_{E U, i} \Delta S_{E U, i, t}+\theta_{b, U S A, i} \Delta S_{U S A, i, t}+\theta_{R O W 2, i} \Delta S_{R O W 2, i, t}+\varsigma_{b, i, t}
\end{aligned}
$$

where $R_{i, t}$ is return on stock market $i$ at time $t, \theta s$ are coefficients to be estimated and $\Delta S_{j, i, t}$ is the change in the effective exchange rate index for country $i$ against region $j$. The composition of regions is given below. The respective share of each country $k$ in group $j$ was calculated for each country $i$ (the MERM-weight of that country divided by the total MERM-weights for that group of countries). Each such weight was then multiplied by the exchange rate between country $i$ and $k$. The sum of these products make up the effective exchange rate of country $i$ versus group $j$.

$S_{j, i, t}=\sum_{k=1} \frac{\text { MERMWEIGHT }}{\sum_{k} M E R M W E I G H T_{k, i}} *$ EXCHANGERATE $E_{k, i}$

If a country belongs to a certain group the calculations were simply done for the rest of that group. Regression results are presented in table 3 below.

SEMU: Austria, Belgium, Germany, France, Netherlands

USA: United States

ROW1:Switzerland, Denmark, Finland, Italy, Japan, Norway, Sweden, Canada, U.K., Australia, Ireland, Spain

$E U$ : Austria, Belgium, Germany, Denmark, Finland, France, Italy, Netherlands, Sweden, Ireland, U.K. Spain.

ROW2: Switzerland, Japan, Norway, Canada, Australia

Table 3 Exchange rate exposure, different areas

\begin{tabular}{l|lll|lll}
\hline Country & $\theta_{\text {SEMU }}$ & $\theta_{U S A}$ & $\theta_{\text {ROWl }}$ & $\theta_{E U}$ & $\theta_{U S A}$ & $\theta_{\text {ROW2 }}$ \\
\hline Austria & -0.602 & 0.612 & 0.281 & -0.133 & 0.191 & 0.241 \\
Belgium & -0.013 & 0.299 & 0.218 & 0.112 & -0.151 & 0.206 \\
Denmark & 0.415 & 0.113 & -0.382 & -0.234 & $0.472 * *$ & -0.033 \\
France & 0.412 & -0.348 & -0.039 & -0.478 & -0.292 & -0.163 \\
Germany & 0.313 & -0.177 & 0.045 & 0.028 & 0.036 & 0.181 \\
Italy & $0.931 * * *$ & -0.160 & $-0.915 * *$ & $0.887 * * *$ & -0.346 & $-0.631^{* *}$ \\
Japan & 0.287 & -0.096 & -0.397 & -0.138 & -0.478 & -0.625 \\
Netherlands & 0.281 & 0.326 & -0.372 & 0.161 & 0.255 & -0.065 \\
Sweden & 0.260 & 0.464 & -0.414 & 0.284 & 0.210 & -0.196 \\
\hline *** significant at $1 \%, * *$ at $5 \%, *$ at $10 \%$.
\end{tabular}

Exposure for some stock markets and regions turn out significant, but most estimates have large standard errors (not reported). 
Table 1 Exchange Rate Exposures for National Stock Markets, 1973:1 - 1996:08.

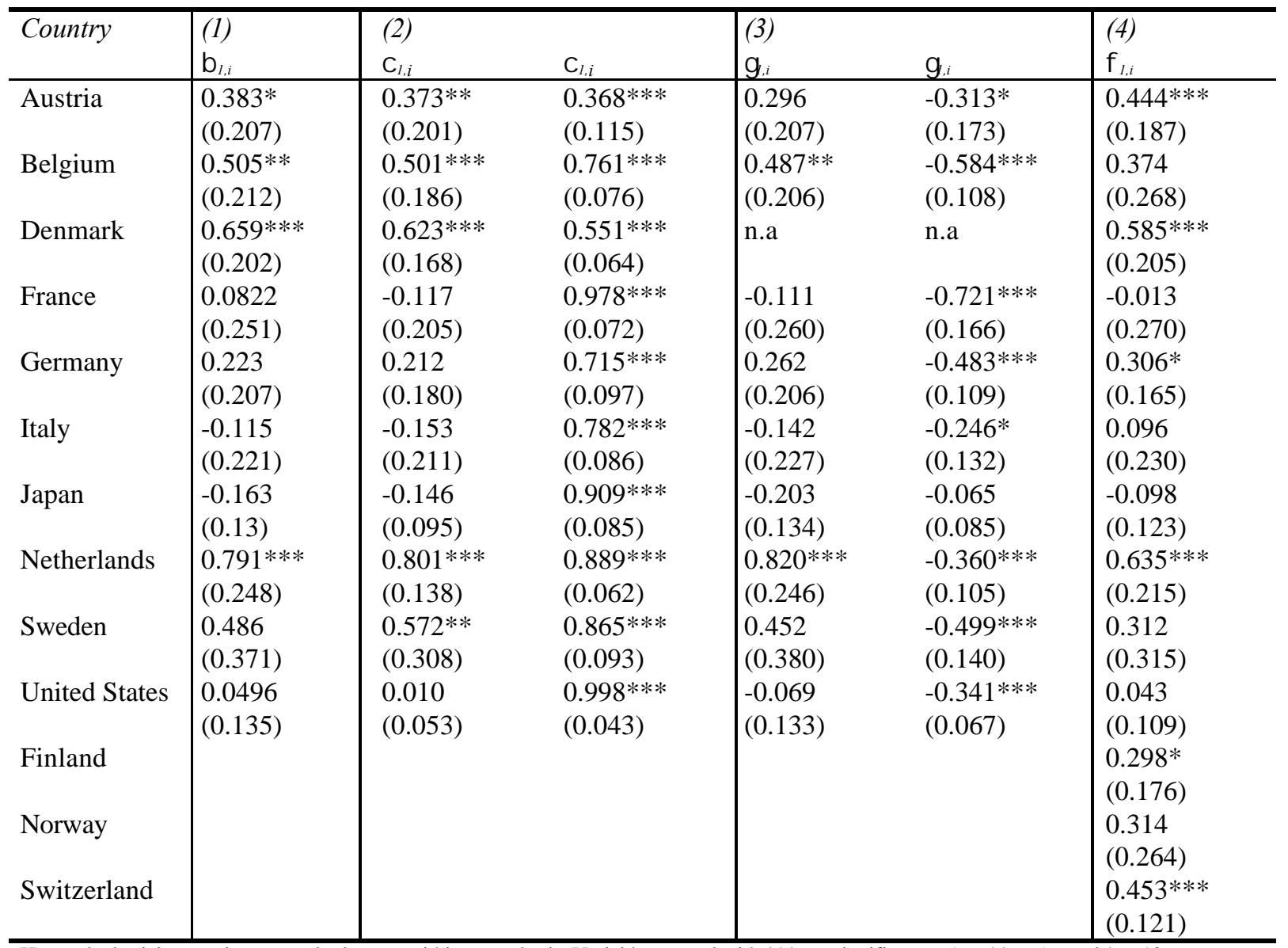

Heteroskedasticity-consistent standard errors within parenthesis. Variables starred with $* * *$ are significant at $1 \%, * *$ at $5 \%$ and $*$ at $10 \%$.

(1) $R_{i, t}=\beta_{0, i}+\beta_{1, i} \Delta S_{i, t}+\varepsilon_{i, t}$

where $R$ is the change in Morgan-Stanley index

(2) $R_{i, t}=\chi_{0, i}+\chi_{1, i} \Delta S_{i, t}+\chi_{2, t} \Delta W_{i, t}+\eta_{i, t}$

where $R$ is the change in Morgan-Stanley index and $\Delta W$ is the change in the Morgan-Stanley world equity index

(3) $R_{i, t}=\gamma_{0, i}+\gamma_{1, i} \Delta S_{i, t}+\gamma_{2, t} \Delta I_{i, t}+v_{i, t}$

where $R$ is the change in Morgan-Stanley index and $\Delta I$ is the change in long-term interest rates

(4) $L R_{i, t}=\phi_{0, i}+\phi_{1, i} \Delta S_{i, t}+\zeta_{i, t}$

where $L R$ is the change in the local index as defined in appendix 1 . 
Table 2. Exchange rate exposures for national stock markets, 1973:1- 1996:08. Real stock returns and real exchange rates, and exposure against US dollar and small EMU.

\begin{tabular}{|c|c|c|c|}
\hline \multirow[t]{2}{*}{ Country } & \multicolumn{3}{|c|}{$R R_{i, t}=\varphi_{a, 0, i}+\varphi_{a, 1, i} \Delta R S_{i, t}+\varsigma_{a, i, t} \quad R_{i, t}=\varphi_{0 b, i}+\varphi_{b, l, i} \Delta U S D_{i, t}+\zeta_{b, i, t} \quad R_{i, t}=\varphi_{c, 0, i}+\varphi_{c, 1, i} \Delta S E M U_{i, t}+\varsigma_{c, .}$} \\
\hline & $\varphi_{a, l, i}$ & $\varphi_{b, l, i}$ & $\varphi_{c, l, i}$ \\
\hline \multirow[t]{2}{*}{ Austria } & 0.171 & $0.190^{*}$ & $0.178^{*}$ \\
\hline & $(0.208)$ & (0.098) & (0.099) \\
\hline \multirow[t]{2}{*}{ Belgium } & $0.465^{*}$ & $0.178 * *$ & $0.174 *$ \\
\hline & $(0.242)$ & $(0.090)$ & $(0.096)$ \\
\hline \multirow[t]{2}{*}{ Denmark } & $0.497 * * *$ & $0.264 * * *$ & $0.268 * * *$ \\
\hline & $(0.169)$ & (0.095) & $(0.096)$ \\
\hline \multirow[t]{2}{*}{ France } & 0.127 & 0.022 & 0.076 \\
\hline & $(0.257)$ & $(0.117)$ & $(0.114)$ \\
\hline \multirow[t]{2}{*}{ Germany } & $0.377 *$ & 0.136 & 0.161 \\
\hline & $(0.206)$ & (0.098) & $(0.104)$ \\
\hline \multirow[t]{2}{*}{ Italy } & 0.322 & 0.109 & 0.269 \\
\hline & $(0.246)$ & $(0.162)$ & $(0.151)$ \\
\hline \multirow[t]{2}{*}{ Japan } & 0.019 & -0.134 & -0.0233 \\
\hline & $(0.140)$ & (0.100) & $(0.088)$ \\
\hline \multirow[t]{2}{*}{ Netherlands } & $0.504 * *$ & $0.355 * * *$ & $0.361 * * *$ \\
\hline & $(0.215)$ & $(0.096)$ & $(0.096)$ \\
\hline \multirow[t]{2}{*}{ Sweden } & 0.291* & $0.363 * *$ & $0.339 * * *$ \\
\hline & $(0.157)$ & $(0.174)$ & $(0.108)$ \\
\hline
\end{tabular}

Heteroskedasticity-consistent standard errors within parenthesis. Variables starred with *** are significant at $1 \%, * *$ at $5 \%$ and $*$ at $10 \%$. 